\section{References}

1. Walls T, Shankar AG, Shingadia D. Adenovirus: an increasingly important pathogen in paediatric bone marrow transplant patients. Lancet Infectious Diseases 2003; 3: 79-86.

2. Two fatal cases of adenovirus-related illness in previously healthy young adults-Illinois, 2000. Journal of American Medical Association 2001; 286: 782-3.

3. Lee JH, Jang JH, Lee SH, et al. Respiratory viral infections during the first 28 days after transplantation in pediatric hematopoietic stem cell transplant recipients. Clinical Transplantation 2012; 26: 736-40.
4. Kim EK, Lee HE, Ko JT, et al. A case of adenovirus infection in the neonate. Journal of the Korean Society of Neonatology 1997; 4: 67-71.

5. Mayeur N, Srairi M, Tetu L, Frugier CG, Fourcade O, Dahan M. Lethal hemorrhagic alveolitis after adenovirus pneumonia in a lung transplant recipient. Heart and Lung: The Journal of Acute and Clinical Care 2011; 41: 401-3.

6. Schmttz H, Wigand R, Heinrich W. Worldwide epidemiology of human adenovirus infections. American Journal of Epidemiology 1983; 117: 455-66.

\title{
Acquired pure red cell aplasia due to anti-erythropoietin antibodies in a patient with end stage chronic kidney disease
}

\author{
H M S Senanayake ${ }^{1}$, K Thirumavalavan ${ }^{1}$, M N Gunasekara ${ }^{2}$, V Ratnamalala ${ }^{2}$
}

Ceylon Medical Journal 2013; 58: 86-88

\section{Introduction}

Anaemia is a common problem in end stage kidney disease. Recombinant human erythropoietin ( $\mathrm{rHuEPO}$ ) is commonly used in management of such patients to maintain optimal hemoglobin levels and to minimise transfusion requirements. Acquired pure red cell aplasia (PRCA) is a rare complication of erythropoietin therapy due to development of anti-erythropoietin antibodies (anti-EPOabs). We report a patient with end stage kidney disease who developed pure red cell aplasia following rHuEPO treatment.

\section{Case report}

A 57-year old man with end stage kidney disease due to diabetic nephropathy, presented with fatigue and exertional breathlessness worsening over six weeks duration. He was on subcutaneous injections of rHuEPO $\left(\right.$ EPIAO $^{\circledR}$ - Shenyang sunshine pharmaceutical co. China,) 4000 units biweekly over one year for anaemia associated with chronic renal failure. He had never been transfused with red cells. On examination he was pale and his hemoglobin level was $3.9 \mathrm{~g} / \mathrm{dl}$. His white cell and platelet counts were normal. Blood film showed normochromic normocytic red cells. The hemoglobin level was maintained around $10 \mathrm{~g} / \mathrm{dl}$ with above rHuEPO dose until two months back when it dropped rapidly. Figure 1 shows variation of the hemoglobin level with time.

The reticulocyte count was very low $\left(2760 / \mathrm{mm}^{3}\right)$ and serum ferritin was elevated $(571.4 \mathrm{ng} / \mathrm{ml})$. Bone marrow aspiration biopsy showed markedly suppressed erythropoiesis with absent normoblasts and proerythroblasts (Figure 2). Granulocytic and megakaryocytic elements were normal. Anti-erythropoietin antibodies (56.6\% - normal up to $4.7 \%$ binding) were detected by radioimmunoprecipitation (RIPA) assay. A diagnosis of acquired pure red cell aplasia due to anti-EPOabs was made. Recombinant erythropoietin therapy was discontinued. Patient was given packed red cell transfusions and started on immunosuppressive therapy with prednisolone $1 \mathrm{mg} / \mathrm{kg} /$ daily. After six weeks of steroid therapy the reticulocyte count rose to $5400 / \mathrm{mm}^{3}$. Currently he is on regular follow up with top up blood transfusions and is undergoing preliminary investigations for kidney transplantation.

${ }^{1}$ Medical Unit and ${ }^{2}$ Department of Hematology, North-Colombo Teaching Hospital, Ragama, Sri Lanka.

Correspondence: HMSS, e-mail: <hemal_@live.com>. Received 9 August and revised version accepted 17 November 2012. Competing interests: none declared. 


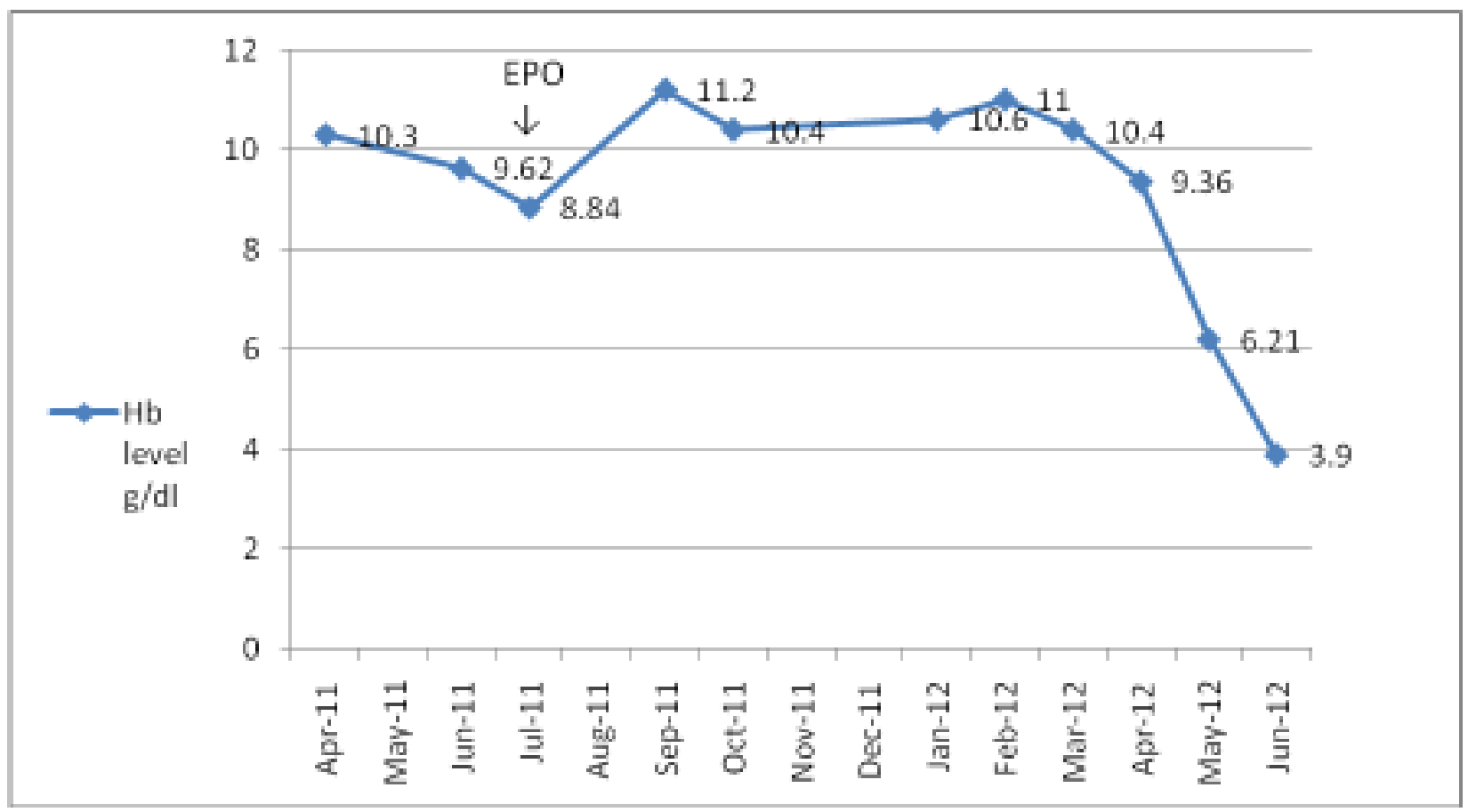

Figure 1. Change in hemoglobin level with time (from April 2011 to June 2012).

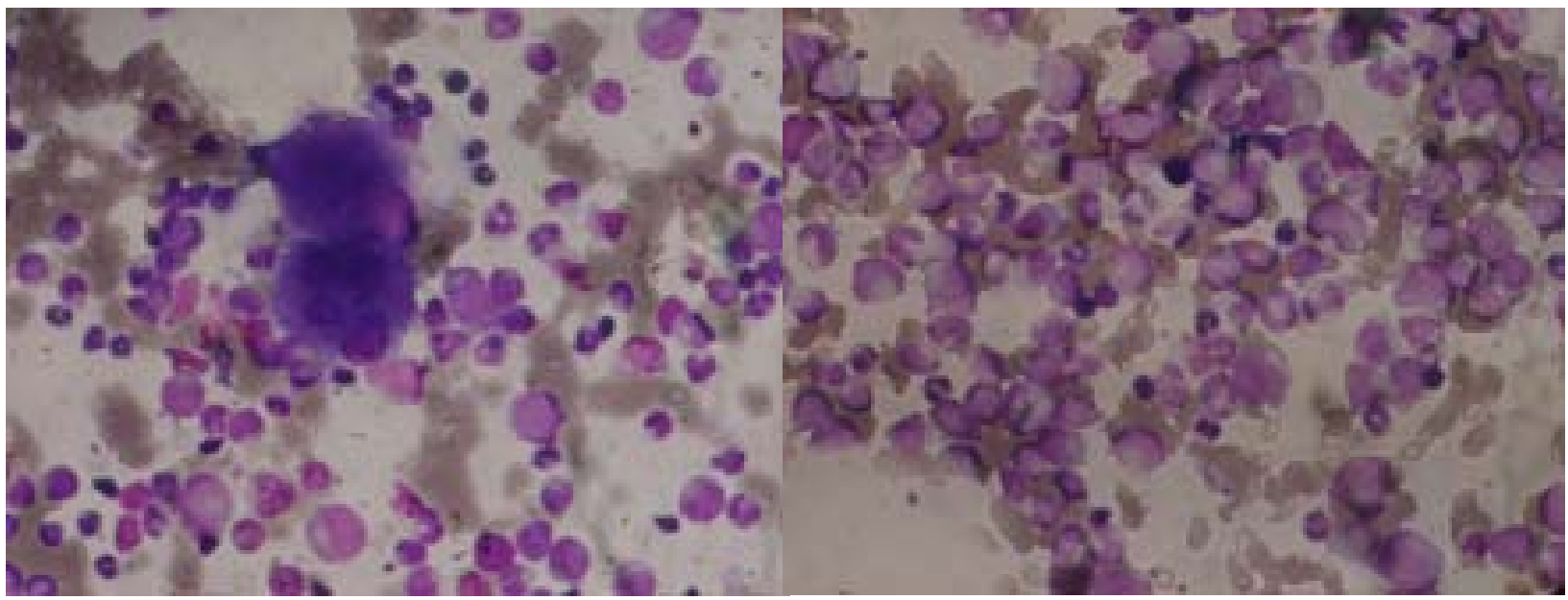

Figure 2. Bone marrow aspirate showing severe erythroid hypoplasia (Leishman stain $\times 400$ ).

\section{Discussion}

Acquired PRCA in patients who are treated with rHuEPO was first described in 1990, ten years after starting its use as a therapeutic agent [1]. It is a rare complication with an exposure adjusted incidence rate of 0.02-0.03 per 10,000 patient-years, and occurs mainly in patients with renal failure who are on long term erythropoietin therapy [2]. Majority of such cases were reported during 1998 2002 and there was a steady decline since 2003 [3]. Currently there are concerns about a surge in PRCA in certain countries (eg. Thailand) due to availability and use of many biosimilar non-patented erythropoietin products at a lower cost $[2,3]$.

Erythropoietin induced PRCA occurs due to formation of anti-EPOab of $\operatorname{IgG}\left(\mathrm{lgG}_{1}\right.$ and $\left.\mathrm{IgG}_{4}\right)$ class which are capable of neutralising recombinant as well as endogenous erythropoietin [4]. The average time to develop PRCA is 9-11 months after starting rHuEPO therapy $[2,5]$. It should be suspected when rapidly progressive erythropoietin resistant anemia develops in 
patients who are on long term rHuEPO therapy. It reflects almost complete cessation of red cell production characterised by very low reticulocyte count $(<10,000$ $\mathrm{mm}^{3}$ ) and a rapid decline of haemoglobin concentration at a rate of $1 \mathrm{~g} / \mathrm{dl} /$ week, reflecting a decay corresponding to normal red cell life span $[1,5]$. There should not be a major drop in white cells or platelets. Diagnosis is confirmed by demonstration of complete absence of red cell precursors in bone marrow with normal white cell and platelet precursors and by isolation of anti-erythropoietin antibodies in serum $[1,5]$. Anti-EPO antibodies can be demonstrated by radioimmuno-precipitation (RIPA) or ELISA techniques $[1,2,5]$. Additionally rapid increase in serum ferritin and transferrin saturation is noted in PRCA, reflecting cessation of erythropoiesis and interruption of iron utilisation [1].

Anti-EPO antibody induced PRCA is usually reversible after discontinuation of erythropoietin therapy and treatment with immunosuppressive drugs [3, 5]. Patients should not be switched to another recombinant erythropoietin product since antibodies cross react $[1,5]$. Cessation of erythropoietin therapy alone without immunosuppressive therapy does not reverse PRCA [5, 6]. Immunosuppressives such as corticosteroids, cyclophosphamide, cyclosporine, mycofenolate mofetil and rituximab have all been used in treatment of anti-EPO antibody induced PRCA with variable success rates [2, 3]. Kidney transplantation is the most effective treatment with complete recovery $[1,2,5]$. Patients need multiple red cell transfusions until normal red cell production resumes. Recently a synthetic erythropoietin receptor agonist, peginesatide, has been successfully used in the treatment of PRCA due to anti-EPO antibodies [2, 3, 4]. Recovery is diagnosed when the reticulocyte count rises $>10,000 \mathrm{~mm}^{3}$ and anti-EPO antibodies are no longer detected [7].
Although anti-EPO antibody induced PRCA is a rare complication, physicians need to be aware of the clinical features and diagnostic procedures when managing patient with anemia due to renal failure. At present there are no reports available regarding the antigenicty of this particular brand of rHuEPO. Continuous vigilance is mandatory as a rise in anti-EPO antibody induced PRCA can be expected due to the epidemic of chronic kidney disease as well as wide availability and use of rHuEPO products at an affordable price in Sri Lanka.

\section{References}

1. Rossert J. Casadevall N. Eckardt K. Anti-erythropoietin antibodies and pure red cell aplasia. Journal of the American Society of Nephrology 2004; 15: 398-406.

2. Macdougall IC, Roger SD, Francisco A, et al. Antibody mediated pure red cell aplasia in chronic kidney disease patients receiving erythropoiesis-stimulating agents: new insights. Kidney International 2012; 81: 727-32.

3. Wish JB. Erythropoiesis-stimulating agents and pure red cell aplasia: you can't fool Mother Nature. Kidney International 2011; 80: 11-13.

4. Macdougall IC. Rossert J. Casadevall N, et al. A pepetide based erythropoietin receptor agonist for pure red-cell aplasia. New England Journal of Medicine 2009; 361: 1848-55.

5. Eckardt K. Casadevall N. Pure red cell aplasia due to antierythropoietin antibodies. Nephrology Dialysis Transplantation 2003; 18: 865-9.

6. Kim MA. Chang SH. Maeng KY. Acquired pure red cell aplasia due to anti-erythropoietin antibodies in a patient undergoing hemodialysis. Korean Journal of Hematology 2005; 40: 45-8.

7. Casadevall N. Pure red cell aplasia and anti-erythropoietin antibodies in patients treated with epoietin. Nephrology Dialysis Transplantation 2003; 18: viii37-41. 